\title{
The Struggle Between Sense and Sensibility Amid Conspiracies--The Love and Humanity in the Film Lust, Caution
}

\author{
Zumei Wei \\ College of Literature and Journalism, Sichuan University, Chengdu, China \\ College of Foreign Languages and Cultures, Sichuan University, Chengdu, China \\ weizumei@163.com
}

Keywords: Lust, Caution; sense; sensibility; human nature.

\begin{abstract}
The hit movie Lust, Caution makes us reminisce the writing style of Eileen Chang. The movie features the struggle between sense and sensibility, the entanglement of desire and emotion, the criticism and sneer of human nature, and the murky struggle behind the pomp and opulence. The features of the three main characters of the film bear the clear mark of the special times and their unique emotions, the fading youth of Wang Jiazhi, the subtle affections of Mr. Yi, and the bewilderment of Kuang Yumin, all reflecting what the director means to tell.
\end{abstract}

\section{Introduction}

The novel Lust, Caution, written in 1950, has been revised many times over the past some 30 years and was published till in 1978 together with other stories Xiang Jian Huan (Happy Meeting) and Fu Hua Lang Rui (Floating Flower Pistil) as a collection. As said Eileen Chang in the preface, "the story has stirred my soul deeply, and that's why I relish revising it over and over for many years and have barely realized that 30 years have passed. Love is something defies questioning." That is what Li Shang yin, a poet in the Tang Dynasty has aptly put it, "such feeling cannot be recalled again, it seemed long-lost even when it was felt then". Yet "looking back the hard journey 30 years ago, even the most beautiful scene of the moon was tinged with loneliness”, wrote Eileen Chang.

Director Ang Lee has added more new elements to the short, simple story from the perspective of a male, leaving a great space for imagination. Without any gaudy dramatic technique, the movie only tells a story free of subjective view and standpoint of the director. In the seemingly cramped space revealed by the movie, a scene of changing human nature is rendered as time and space change.

The painstaking efforts of the writer over the past 30 years have been crystallized as such a simple story of assassination against a traitor. Despite that other similar plots have been featured in many mainstream movies, Lust, Caution, thanks to the magic touch of Ang Lee and the perfect combination of sound and pictures, exudes a special layer of luster. It's a story about "the lustful relationship between a hunter and his prey, between a tiger and its quarry, which means possessing in the fullest possible sense".

The backdrop is Shanghai during the Anti-Japanese War, an eventful era, when the puppet government of Wang Jingwei was cold-blooded in killing and all sorts of atrocities. Against the gloomy scene, a group of patriotic youths realized that they were duty-bound to save the nation from the edge. The movie features a schoolgirl who tried to seduce the traitor amid the subtle changing of personal character and the intricacies of human nature and conspiracies. The features of the three main characters of the film bear clear mark of the special times and their unique emotion, the fading youth of Wang Jiazhi, the subtle affections of Mr. Yi, and the bewilderment of Kuang Yumin, all reflecting what the director means to tell.

\section{Wang Jiazhi-Fading Youth: Imaginary Affection and Tender Sensibility}

As the leading actor of the campus drama troupe, Wang Jiazhi lost her virginity because of an immature assassination plan, "everyone is avoiding her, and does not look at her when discussing something”. On such occasions, the feeling of Wang Jiazhi defies the simple word of consolation that, 
“among all these people I'm the most foolish one". It's not so much that she indulged in the fleeting gentle affection of Mr. Yi as she was desperate to grasp a trace amount of comfort with imaginary love. Amid the vague warmth, the girl has finally found something she believed to be love after the struggle between sense and sensibility. Lust overpowers caution as she tried to save her lover at the cost of her own life. Women are creatures of feelings and need more comfort in a relationship. During the four years in the movie, what she needed most was a sense of security and the protection of a mature man.

Ang Lee has said, “There's a Brokeback Mountain in the heart of everyone” (here the "Brokeback Mountain" means a love that will never fade). Wang Jiazhi has always wanted to return to the "Brokeback Mountain", yet she had to face the harsh reality. What gets broken is not backbone, but the original feeling. It may be the feeling towards a person or a matter. You have poured all your passion and tried to hold him back and yet in vain. Deep inside of the heart of everyone, there is some feeling lost forever in the tunnel of time.

In a split second, Wang Jiazhi "realized that the man truly loves me, and at that very moment, she felt something was lost forever-yet it's too late." It's the word "it's too late" that deprived her of the bewildered love and forced her to face a bloody world.

\section{Mr. Yi-the Subtle Affections: the Destroyed Sensibility and Struggling Conspiracy}

In the face of Wang Jiazhi's seduction, Mr. Yi answered with flirtation. A life of high pressure meant that he believed nobody. Yet over time, his cold bloodedness and cruelty have somewhat subsided the time facing the affection of Wang, which made him believe that "She is the first soul mate of him. As a middle-aged man, I've never expected to meet such a person". In the Japanese club, he shed tears while listening to the song Tian Ya Ge Nv (Song Bird). After she was executed, he stood in the hotel alone, looking blank at the wrinkles on the white bed sheet. All these details exude his inner world.

The emotional outburst of Mr. Yi contrasted sharply with his grim face.

In the film, the lip print of Wang Jiazhi has been printed in coffee cups on several occasions, which divulged her real identity. For real ladies, it's impossible for them to use cheap lipstick that makes such a gaffe. All these cannot escape from the eyes of Mr. Yi, a seasoned special agent. Being suspicious of Mrs. Mai's real identity, he still relished playing the game with her, in that troubled times. A middle-aged man, cold in appearance yet tired and helpless at heart, found a measure of pleasure while being with such a clear and slick woman, which made him temporarily forget the exhaustion brought by apprehension and fell in love with her gradually.

At the end of the film, Mr. Yi signed the warrant of execution. In the cold reality, the affection between a man and a woman cannot rival intrigues and interests. When it comes to a relationship, pleasure makes men feel contented, while women want real love, which means women are always the most hurt one.

\section{Kuang Yumin-Bewilderment: Hopelessness and Timidness}

A timid but patriotic young man sought to materialize his patriotism at the expense of the chastity of the girl he loved yet never expressed his heart to. Three years later, he finally found her but entrusted the same task to her while suppressing his real feeling again. Later, while realizing that he might lose her forever amid the changing world, he kissed her at downstairs yet was pushed away. "It's what you should have done three years ago, why not then?” Wang asked bitterly.

The sadness behind the question indicated that everything was beyond his imagination and he has already lost her. If he could have consoled her and shouldered more responsibility on an early day, what the result might be? Breaking away from the previous practice of trying to shape a perfect character, Ang Lee has created a timid and selfish intellectual who was radical in patriotism yet coward in personal emotion. Both the passiveness and perseverance of the same person have been incisively and vividly portrayed, leaving a feeling of desperation. 
As the execution came, what's in the eyes of Kuang Yumin, pity and sympathy, guiltiness and regret, or dissatisfaction and indignation? Without a word, the film concludes with a heavy ending.

The simple story featuring characters with multi-dimensional personalities has broken the stereotype that good guys are perfect and bad guys are incurably bad, and depicted characters as what they should be like, thus revealing complex human nature more deeply and truly. The film is of high aesthetic value and has stirred the hearts of audiences from all perspectives. Different from the early films of Ang Lee, which are full of philosophical meaning, Lust, Caution is very easy to understand and highlights the ultimate concern towards humanity. Humanity is the most prominent theme of Lee's film, where everyone seems to be in a struggle and cannot escape from being interrogated and reviewed.

"The moon 30 years ago has sunk for long, and people 30 years ago have all died. Yet the story 30 years ago is still going on, and it has no end."

\section{Conclusion}

Lust, Caution was a novel published by Flower City Publishing House in 1997 and created by author Eileen Chang in 1950. It was published in her sub-collection The Book of Frustration 30 years later. Lust, Caution mainly depicts the story of an educated young woman turning herself into an assassin in the end of 1930 and attempting to use her beauty to ensnare a high-rank agent who worked for Wang Jingwei. The two cheated each other in regards of politics, tactics, and sexual relationship. On April 11th, 1978, the novel Lust, Caution written by Eileen Chang was published in the supplement Human World of the China Times. Later, Eileen Chang remarked in the preface of Sequel published by the Crown Publishing House in 1988 that she started to conceive the ideas of Lust, Caution in 1953. In 1983, the Crown Publishing House published The Book of Frustration. Again, Eileen Chang commented in the preface on Lust, Caution, Joy at Meeting and Floating Flowers and Wandering Pistils: "These three little stories have hit me the most emotionally, thus I was willing to rewrite them again and again over the years. I even just wanted to gain the feeling of surprise and joy as I first conceived the story and I treasured the journey of heart during rewriting these stories. What I did not realize was that 30 years has passed.” Thus, from 1953 when Eileen Chang started to conceive the story of Lust, Caution, to 1978 when the story was published, 25 winters and summers have gone by.

In Eileen Chang's novel, what I can see is only the touching feelings by Mr. Yi towards Wang Jiazhi instead of any love or affection. However, in Ang Lee's movie, at the end where the actor Tony Leung sat at the edge of the empty bed, touching the edge of it, which once harbored the affection between him and Wang Jiazhi. With eyes full of tears, he couldn't help convulsing his face nor concealing the sorrowfulness written in his facial expressions. Undoubtedly, he has loved Wang Jiazhi.

Ang Lee was a warm person, and it is appropriate to use one expression to sum up the whole novel: fake play yet with true affection. When I watch the end of the movie, where Mr. Yi sat alone in the room where Wang Jiazhi once lived, caressing the bed to feel the fading past affection, and casting his long and lonesome shadow when he left the room, I would rather believe that he has loved her. However, Wang Jiazhi lost the game between the hunter and the prey in the beginning. In the novel, Eileen Chang cleverly combined her stage performance experience (she was the diva in the drama club) with her experience of being a spy. It is said that life is like a play, and a play is like life. Is it easier for Wang Jiazhi to accept that having a romantic relationship with Mr. Yi was like playing a role in a play? However, in the movie, the boundary between a play and real life started to be indistinct and vague. No madness, no survival. Wang Jiazhi went to see Kuang Yumin, seemingly reporting information, but was rather more like a mistress nagging her emotions. I see an addicted and mad Wang Jiazhi who couldn't detach herself and was walking on the brink of a mental collapse.

Love in the hell was so true as it was in the dark. 


\section{References}

[1]. Ma Rongrong. The Lust and Caution of Ang Lee [J]. Sanlian Lifeweek Magazine, 2007, (36).

[2]. Eileen Chang. Wang Ran Ji [M]. Guangzhou: Huacheng Publishing House, 1997.

[3]. Li Dahan. Mountain after Mountain--Ang Lee’s Lust, Caution and Brokeback Mountain [M]. Taiwan: Ruguo Publishing House, 2007. 